\title{
Technique of empire: Colonisation through a state of exception
}

\author{
Gerard Emmanuel Kamdem Kamga
}

University of Pretoria \& University of the Free State

CONTACT: Gerard Emmanuel Kamdem Kamga, gerard.emmanuel@gmail.com

\begin{abstract}
The main argument of this article lies in its conceptual framing which is a contextualisation of the problem of exception in the colonial and 'postcolonial' period of Cameroon. The country was technically colonised by Germany and following the Versailles treaty, was later transferred to France and Britain under a mandate of the League of Nations. Following legal and historical investigations, I assess how the permanent recourse to a state of exception within the colony was central to Europeans' tactics in their strategies of control and domination of colonised people. I further examine how the country's colonial past strongly influences current state structures through a basic reliance on emergency laws which have become normalised to a point where the law's force has been reduced to the zero point of its own content.
\end{abstract}

\section{Keywords}

state of exception; state of emergency; colonialism; Cameroon; violence; rule of law; human rights; democracy

In this article, ${ }^{1}$ I intend to expand on a technique repeatedly used by French colonial authorities to weaken and annihilate the struggles of independence in Cameroon, a technique which is still in force today and aims essentially to sideline political challengers and paralyse democracy. This technique is a legal institution which appeared for the first time in medieval canon law and is currently known as a state of exception. At the onset, I want to be clear about the fact that it is not my intention to review the historiographies of the colonisation of Cameroon, but to shed light on a legal/illegal/political phenomenon, a technique of empire that was instrumental to sabotage the liberation's struggle led by a nationalist movement namely, the Union des Populations du Cameroon (UPC). ${ }^{2}$ Despite an important amount of available literature, ${ }^{3}$ several grey areas still persist especially when it comes to the rationale behind the normalisation of atrocities linked to colonialism. The information that has been available for decades was in fact the official version from the French authorities and their local acolytes; information clothed with ideological propaganda through which the nationalist dimension of the struggles perpetrated against French colonialism was covered up and the nationalist fighters portrayed as a handful of discontented people bloodthirsty of their countrymen and manipulated from outside by the communists (Mbembe 1964). To correct this misperception, one can now rely, as Frederick Cooper put it: 
Some of the best studies of post-world War II politics focus not on the parties that took over the state but ... on the guerrilla movement of the Cameroon, which the French successfully marginalised and destroyed ... (1994: 1540)

Since the release of various archives, interviews and publications of their memoirs by some direct protagonists, all reported in recent publications (see Deltombe, Domergue \& Tatsitsa 2016 \& 2011), it appears that the basic modus operandi of French colonialism in Cameroon was constructed on the idea that the colonial is the state of nature where society's institutions have no place (De Sousa Santos 2007). Very little attention has been given to the use of a state of exception as a technique of empire in African colonial historiographies in general and Cameroon in particular. Assessing the role of a state of exception within the context of French colonialism in Cameroon is in line with Frantz Fanon's ( 1963) contention according to which it is only through interpreting history from the perspective of the colonised that the full picture can finally be seen.

The core of my argument in this analysis revolves around a state of exception, an institution clothed with legal attributes which paradoxically has the power to initiate the stand-still of the law and provide room for what Fanon (1963) referred to as naked oppression. As a starting point, it is crucial to understand that Cameroon was colonised by Germany and was later placed under British and French administrations through a mandate of the League of Nations. This means that in a technical sense, Cameroon (like Togo) has never been a French and British colony, but a territory that was withdrawn from Germany and placed under the responsibility of the League of Nations. Indeed, Germany that was defeated during the first world war lost its African colonies (of Kamerun and Togo) to the profit of the League of Nations which requested France and Britain to ensure peace, law, order and administration in these territories. As a resultant, the then territory of Kamerun (the German spelling) was divided into two sections, one placed under French control and the other under British influence. The analysis I am about to provide will be focusing essentially on the French section which at the time was subject to the brutal politique d'assimilation that had drastic implications, for it compelled indigenous Cameroonians to forget about their customs and traditions and adopt French culture; a ruling system fundamentally different from that of its British counterpart, instead based on the (soft) system of indirect rule characterised by local administration by indigenous authorities over their own population. By the end of the First World War, Cameroon had shifted from being a German colony to becoming a de facto French-British colony. As one might reasonably expect, replacing one colonial system by another imperialist system could not have logically improved the condition of the colo-nised given that similar causes result with similar effects. Colonialism is generally under-stood to be an encapsulation of political and economic relations in which the sovereignty of a nation or a people rests on the power of another nation, which sets up direct colonial administration (NdlovuGatsheni 2012). Achille Mbembe (2001: 25) has observed that the colonial model was, in both theory and practice, the exact opposite of the liberal model of debate and discussion; inflation of right in that, except when deployed in the form of arbitrariness and the right of conquest, the very concept of right often stood revealed as a void. And here we find ourselves in the presence of what Boaventura de Sousa Santos refers to as the 'abyssal divide between regulation/emancipation and appropriation/violence' (2007: 54). In 
other words, in the presence of the universe of western modernity which is characterised by the coexistence of the state of nature and civil society separated by an abyssal line where the hegemonic eye, located in the civil society ceases to see and indeed declares as nonexistent the state of nature (De Sousa Santos 2007). It is in such circumstances that in April 1948, the Union des Populations du Cameroun (UPC), a nationalist movement came into being. The movement which was led by Ruben Um Nyobe demanded nothing but independence and reunification of British and French Cameroons; in other words, the movement was claiming the former territory of Kamerun which at the time was divided into two sections administered by France and Britain. Through an important deployment of legal means including nationwide rallies, organised protests, publications and awareness campaigns, the UPC's struggle against colonialism took shape and the movement won wide support and sympathy among indigenous populations who became aware of their condition. French authorities quickly assessed the efficiency of the nationalist movement and assumed that 'all democratic means to fight against the UPC were destined to fail' (Deltombe, et al 2011: 27). This eventually led the French system of governance to reveal the state of nature by setting up repressive machineries in the portion of the country subject to their influence. In so doing a state of exception was introduced in the early French Cameroon institutions and was to be subverted and instead used as a technique of domination and subjugation of the colonised people.

Within the regulation/emancipation paradigm, a state of exception is normally enforced in exceptional circumstances namely, war, revolution, natural cataclysms and threat of invasion, allowing states legally to suspend laws and infringe human rights when coping with a threat. This institution vests the government with sweeping powers and allows for the possibility to rule by decree, establish curfews, restrict the movement of persons and properties to administrative permissions, arrests without warrant and monitor meetings and publications. A state of exception embodies the concept of 'full powers' characterised by a concentration of power in executive hands and the provisional abolition of the distinction of legislative, executive and judicial powers (Agamben 2005). As observed by Carl Schmitt:

What characterises an exception is principally unlimited authority, which means the suspension of the entire existing order. In such a situation it is clear that the state remains, whereas law recedes. (1985: 12)

The purpose of the exception is therefore to protect and guarantee the existence of the state through the suspension of law. Within the context of Cameroon, a step back in the 1950s accounts for the fact that French authorities and their local collaborators repeatedly implemented a state of exception and a state of emergency not for the sake of protecting the state but to impair the democratic game and brutally repress the struggle of independence and reunification claimed by the UPC. The killing of Cameroon nationalist leaders such as Ruben Um Nyobe, Felix Moumie and Ernest Ouandie and the slaughter of hundreds of thousands of indigenous Cameroonians (mainly from the Bamileke and Bassa tribes) by the French army are some examples in point (Deltombe, et al 2016). Between the colonial period and 1992 the country has recorded more than 100 decrees declaring states of emergency; and these only reflect the cases that were declared as such, as provided for by local and international legislation on the issue. However, none of these decrees was linked to natural cataclysms, war and threats of invasion. Yet historically 
there have been various exceptional circumstances that could have justified the enforcement of a state of exception in the country but authorities chose not to seize these opportunities. Indeed, experiences show that natural cataclysms such as the repeated volcanic eruptions (1959, 1982, 1989, 1999 \& 2000) of Mount Cameroon, the deadly gas emission of Lake Nyos in the northwest region of the country, which on 21 August 1986 suffocated over a thousand people and thousands of livestock, or gas emission from Lake Monoun in the western region, which on 15 August 1984 resulted in the death of 37 people, or the threat of invasion during the war between Cameroon and Nigeria regarding the Bakassi peninsula in the 1990s have ever led to the declaration of a state of exception. Similar observation also applies to the current terrorist activities by the extremist movement Boko Haram in the northern region of Cameroon. Boko Haram, which arose and developed in Nigeria, has crossed into Cameroon and has been the key element of insecurity through kidnappings, suicide attacks, recruiting militants, spreading death, and theft of livestock. The consequences for peace, human security, socioeconomic and political life of the state are considerable. Instead, by relying on a state of exception as a technique of empire, Franco-Cameroon authorities successfully hunted down, imprisoned, tortured and killed with total impunity, leaders of the UPC movement who have been fighting for their right to self-determination.

A further motivation that fed my interest for the technique of empire is that the use of a state of exception as a technique of domination and governance by French colonial authorities in Cameroon did not fade with the colonial era. Since the so-called independence of the country in January 1960, authorities have been inclined to invoke a state of exception as in the past; that is a major political device which is not enforced in times of crisis, but essentially during pre- and post-electoral campaigns to sideline political opponents and ensure the survival of the regime. Such was the case following the controversial presidential elections in 1992 when a state of emergency was imposed in the northwest region, stronghold of the main opposition party as a response to massive electoral fraud of which the regime was accused. In such circumstances, the exception in the country eventually reached its extremity, for the society seems to be operating in an environment where citizens appear to be a mere potential threat to the safety of the ruling class. The recent release of counterterrorism legislation singularised by the (re) introduction of capital punishment for both the perpetrators of terrorist crimes and 'whoever' ' disrupt the national functioning of public services' or 'create widespread insurrection in the country', ${ }^{4}$ the legalisation of mass espionage activity to the profit of the president, ${ }^{5}$ and the creation of so-called secondary prisons are an indication that the exception in Cameroon society has lost its exceptional character and clearly account for a global civil war where the government has the privilege to confront its own population.

In this article, to properly account for the use of a state of exception as a colonial technique, I shall follow a legal and historical analysis to assess how the permanent recourse to this institution within the colony was central to Europeans' tactics in their strategies of control and domination of colonised people. I shall further examine how the country's colonial past strongly influences the current state's structures through a basic reliance on emergency laws which became normalised to a point where the law's force has been reduced to the zero point of its own content. But before investigating these issues, it is crucial first to understand the historical background and Christian origin of a state of exception. 


\section{A brief historical background and Christian origin of a state of exception}

From a historical perspective the idea of putting the rule of law on hold following a crisis originated from the canonical maxim necessitas non habet legem which means 'necessity knows no law' or 'necessity creates its own law'. Rooted in the jus commune, the idea that necessity can, in exceptional circumstances, be considered an excuse for not complying with the rules is very old and widespread (Roumy 2006). An example is given in Seneca's Rhetoric controversies, of a soldier who, having lost his weapons during a battle, took the weapon of another soldier who had died and been buried. Although he emerged from the battle on the winning side, this soldier was accused of invading the grave (Roumy 2006). The author justifies these acts by referring among others, to the lex Rhodia de jactu, and by asserting the following:

Necessity requires a ship's cargo to be thrown away in order to lighten it; necessity requires the demolition of houses in order to extinguish fires; necessity is the law of the moment. (Roumy 2006: 304)

In the $12^{\text {th }}$ century or at the beginning of the $13^{\text {th }}$ century, at least five branches of medieval knowledge including liturgy, theology, philosophy, narrative literature, and civil law had received the maxim (Roumy 2006). Concerning civil law, Ennio Cortese asserts that the maxim necessitas non habet legem was borrowed from the canonists as it appears on the first page of a manuscript of Gratian decree in the Digestum vetus discovered in 1952 by Guido Rossi (Roumy 2006). It is therefore evident that necessitas non habet legem was meant to be a circumstantial remedy aiming at addressing a particular emergency and the law's weakness.

However, this approach has hardly been considered within the context of colonialism in general and particularly in the case of Cameroon. The current picture is different and accounts for the situation where instead of being a temporary and exceptional remedy to the law's weakness, a state of exception in the country has become the foundation without which the legal political system might collapse. In other words, far from being a legal and constitutional device at the service of human rights and the rule of law, as in the regulation/emancipation paradigm, colonial powers have ruled out these premises and instead preferred to rely on a state of exception simply as a technique of empire in accordance with the appropriation/violence paradigm.

\section{The legal framework of a state of exception in pre-independent Cameroon}

After the First World War, possession of Kamerun (the German spelling) was transferred from Germany to France and Britain by virtue of section 119 of the Versailles treaty of 28 June 1919. A few times after French authorities took over the largest portion of the territory, the French royal ordinance of 17 November 1840 on the government of Senegal and its dependencies were enforced in that area. This document essentially contains some emergency provisions, for it provides that 'the governor shall ensure the security and peace of the colony' and that 'all acts and events likely to undermine public law and order or the peace shall be immediately referred to him' (Bouvenet \& Bourdin 
1956: 119). Similarly, a decree issued by the French president of the time, Emile Loubet on 9 November 1901 also became enforceable in Cameroon. Two provisions of this decree regulating the relations between the governors and senior commanders of the troops clearly refer to situations of emergency that may happen in the colonies. ${ }^{6}$ The special powers of the governors of the colonies were later transferred to the commissioner of the French Republic by a decree of 23 March 1921 relating to his prerogatives in Cameroon. Section 2 of this decree conferred upon the Commissaire de la République powers of defence of the territory to be exercised under the authority of the minister of overseas territories of France. ${ }^{7}$

Introducing a state of exception in Cameroon allowed the French to extend to the country some draconian measures already in force in their colonies, which was also provided for by international instruments that endorsed French control over the territory. Section 26 of the League of Nations, which came into effect on 20 July 1922, placed the country under the regime of mandate and vested France and Britain with powers to ensure peace, law, order and administration. In addition, section 3 provided for 'special powers' to the benefit of France and Britain who could use indigenous troops to fight threats following events of war or defence of the territory. The idea of the exception is also spelt out in section 7 which entitled the mandatory powers to 'take all necessary measures' to maintain public order and a good administration. The recurrence of expressions such as 'meetings that can disturb public order', 'all necessary measures', 'special powers', 'law and order' and 'security and peace of the colony' are consistent with the dichotomy between appropriation/violence well designed for the colonial territories (De Sousa Santos 2007). At the time, Cameroon was not yet an independent entity and this explains why the country was ruled by colonial legislation 'imported' from other colonies. The upcoming development portrays how these exceptional measures were used not for the sake of the country but to impair the struggle of independence and reunification of the state.

\section{State of exception in pre-independent Cameroon}

This section examines the harassment campaigns and concentration camps as the matrix of a state of exception and the shift from de facto to de jure emergency.

\section{Harassment campaigns and concentration camps}

The Second World War which broke out in 1939 had highlighted the weaknesses of the League of Nations and led to the creation of the United Nations (UN) in 1946. This resulted in the two mandated territories of Cameroon being converted into UN Trust territories. With regard to a state of exception, section 4 of the trusteeship agreement allows for the setting up of military, maritime and airforce headquarters and entitles authorities to:

take all necessary measures for the organisation and own defence to ensure the participation of the territory to the maintenance of peace and international securities, respect of interior order and the defence of the territory.

However, these provisions were instead implemented in the framework of colonialism and political contestation under the aegis of Um Nyobe and the UPC. The movement 
demanded nothing but independence and reunification of the British and French Cameroons, a request acknowledged by two UN resolutions in January 1952 and December 1953 which required France's trusteeship in Cameroon to move toward autonomy or independence. Being embarrassed by these developments, the French incited the UPC into violence by subjugating the party to social, political and even religious harassment. The French Catholic Church in the country referred to the UPC as the 'organisation of Satan' (Deltombe, et al 2011: 121). As a result, militants of the movement were excommunicated and their children were denied the sacrament. Similarly, in April 1953 Um Nyobe was denied holy sacraments by the American Presbyterian mission in Douala, on the ground that 'faithfulness to communism' is incompatible 'with faithfulness to Jesus-Christ' (Deltombe, et al 2011: 122-3). As time went by this campaign of harassment was intensified and on 5 March 1955 upon his return from the ninth session of the UN, Um Nyobe was summonsed by a judge. Houses and headquarters of nationalist leaders and their supporters were systematically searched. On 19 February 1955 Roland Pre, the French high commissioner in Cameroon issued a decree empowering all the workers of the administration to 'use force in order to prevent and disperse meetings that can disturb public order' (Deltombe, et al 2011: 163). This decree was about enforcing a state of exception as it vested the police and other civil servants with exceptional powers and they became de facto part of the security apparatus of the system. The meetings targeted by the decree were obviously the UPC's meetings. The police and the gendarmerie empowered with such sweeping powers could therefore interrupt nationalist meetings at will and find pretexts for judicial action (Deltombe, et al 2011: 163). As a result, campaigns of arrest, intimidation, and discrimination recurred against the UPC and its sympathisers and in May 1955 led to a generalised atmosphere of violence across the country. On 15 May in the city of Mbanga, at the heart of the Mungo division, the police succeeded in dispersing an unauthorised UPC meeting. On the following day, another meeting was dispersed, and this was repeated on 22 May. But this time, the leaders of the movement and the inhabitants of the area confronted the police. The situation degenerated into uncontrolled violence and escalation of repression in the main areas of the country such as Douala, Yaounde, Nkonsamba, Sanaga-Maritime division, and the western province. On 13 July 1955 a decree issued by the president of the council, Edgar Faure eventually banned the UPC when a court in Yaounde pronounced the confiscation of its assets. On the following day, about 800 followers and militants were imprisoned (Deltombe, et al 2011: 177).

It is noticeable the extent to which colonial authorities hypocritically resorted to a variety of exceptional powers to prevent a nationalist movement to exist and claim their right to self-determination, freedoms of association and movement. The draconian measures implemented by the French administration were alien to the safety of the national territory and aimed essentially at infringing nationalist initiatives which ineluctably led to the prohibition of the UPC by French presidential decree. These developments are consistent with De Sousa Santos' belief that 'in its modern constitution, the colonial represents not the legal or illegal, but rather the lawless' (2007: 49). The atmosphere across the state was peaceful until French authorities decided to issue decrees vesting the state apparatus and other civil servants with exceptional powers. The UPC, with the support of their French lawyers, attempted for many months to obtain a cancellation of this decision through the Council of State and via complaints to the UN, but without success. As a result, part of its leadership, including its chairman Felix Moumie and his 
deputies Abel Kingue and Ernest Ouandie, went into exile. Another section, led by its secretary general Um Nyobe, went underground and began waging guerrilla warfare known in Cameroon as the maquis. Maquis refers to a non-conventional war or guerrilla warfare through which nationalist fighters in Cameroon, being aware of their inferiority and weaknesses in front of a well-equipped French army, avoided open confrontations, remaining hidden in the forest and organising sporadic strikes in the cities. Through such acts of violence, the UPC movement had initiated an extended armed resistance movement against French occupation. The maquis spread around the country and became very active in the Sanaga-Maritime division, hometown of Um Nyobe, and in the Bamileke division in the western region. This was to turn the hostile social and political atmosphere of the country into a lawless space. In response, a genuine campaign of terror led by the French administration resulted in torture, killings, and the deportation of 'terrorists'. Security became the main concern for the inhabitants in various areas which was then an opportunity for the French to escalate repression and crack down against the insurgents including an important portion of the population. On 21 December 1956 Pierre Messmer the new French high commissioner in the country intensified the state of exception by enacting 'special requisitions' allowing security forces to open fire on saboteurs caught in flagrante delicto. This was in response to the sabotage of communications per-petrated by the maquisards. A day later, a Zone de maintien de l'ordre de la Sanaga-Mariime (ZOE) (zone of law enforcement of Sanaga-Maritime) was setup for two months (Deltombe, et al 2011: 214). This resulted in police, gendarmerie, and Cameroon guards' patrols and raids in Douala, Yaounde, Nkonsamba, Bafia, and elsewhere. The Sanaga-Maritime division was in a state of exception and this situation had nothing to do with some sort of natural cataclysms or threat of invasion by a foreign army, for it clearly accounted for a situation of warfare where the attackers were to be found within the borders of the state. Implementing a state of exception within the framework of struggle for independence and reunification was a signal that the right to selfdetermination that the UPC had been fighting for was strongly opposed to the very idea of rights. This use of a state of exception reinforces De Sousa Santos's approach regarding western modernity:

More broadly, it appeared that western modernity can only spread globally to the extent that it violates all the principles upon which it has historically grounded the legitimacy of the regulation/emancipation paradigm on this side of the line. Human rights are those violated in order to be defended, democracy is destroyed in order to safeguard democracy, life is eliminated in order to preserve life. (2007: 57-8)

With regard to the concentration camps, in the quest to contain the UPC's struggle, France experienced one of the techniques of revolutionary warfare when setting up what was labelled a zone d'exception (zone of exception) and a zone interdite (prohibited zone) (Deltombe, et al 2011: 279). These expressions have been used to conceal the true nature of what they represented: the camps. Giorgio Agamben (2005) defines concentration camps as places in which the most absolute conditio inhumana ever to have existed on earth were realised. He considers the camps to be the 'hidden matrix' of the politics where the exception becomes the rule. In Algeria from 1957, these policies have already established approximately 400 camps led by the prefect Maurice Papon, who proscribed the use of the word 'camp' to avoid criticism (Deltombe, et al 2011: 264). The first constitution of a camp in Cameroon appeared under the acronym ZOPAC which stands for 
Zone de pacification de la Sanaga Maritime, literally meaning pacification's zone of the Sanaga Maritime. From 26 December 1957, the population of the Sanaga-Maritime division were forcefully deported from their villages and gathered in a single concentration camp under the control of armed soldiers while their farms and houses were destroyed. The purpose of the French acting this way was to isolate the maquisards who had been living and hiding in the forest while taking advantage of being informed and supplied by their families and friends who still remained in the villages. Within the ZOPAC, the law was no longer applicable, except the one issued by soldiers. The ZOPAC was established to 'welcome' rebels and people who did not deserve to live in a saintly society. At some point the repressive campaigns led by French authorities across French Cameroon were characterised by some sort of tribalism which has since become the very essence of the political system in Cameroon. As Um Nyobe came from the Bassa tribe that were and still are the predominant inhabitants of the Sanaga- Maritime division, people from this tribe who have been living outside the division, for instance in the capital city Yaounde, were hunted down and forcefully returned to their home village which had become a space where the law was no longer applicable (Deltombe, et al 2011: 265). Additionally, when the entire population of the Sanaga-Maritime division was gathered in the camps, the remaining part of the region characterised by unoccupied houses, markets and farms became a zone interdite, meaning that people who were found in these areas or in their houses or farms were automatically 'hors-la-loi' (outlawed) and became targets and mercilessly treated. A state of exception was therefore enforced in two spaces which overlapped each other, the camps and the prohibited zone. At some point, one would have considered that the division of the colony into spaces of exception and prohibited areas would mean less lawlessness in one area than the other. But this scen-ario must be ruled out in the sense that people living inside and outside the camps in the SanagaMaritime division were simply caught within the same divided and lawless space available across the entire colony. This measure, like the previous ones, had the same purpose which was to weaken and paralyse the struggle of independence and reunification. These exceptional measures have been implemented especially to target one association, the UPC movement. It is crucial to notice how the characteristics of a state of exception were manifest. There was no law per se as the country was basically ruled through emergency decrees issued by the French high commissioner. There was neither separation of powers with checks and balances nor judicial review mechanisms both of which are only applicable within the paradigm of regulation/emancipation designed for the metropolitan world. Yet all these principles were part of the French constitution. It is in this sense that a state of exception as enforced within the context of Cameroon was a mere technique of empire, a strategy of control and domination of the colonised.

\section{From de facto to de jure emergency}

Until 1959, the campaign of suppression and deployment of brutal measures across French Cameroon had been carried out mainly through emergency mechanisms provided by French colonial legislation from other colonies and by emergency decrees designed by French authorities in the country. This state of affairs ended in May 1959 when, faced with violence and insecurity perpetrated by the UPC, Prime Minister Ahidjo formally requested legal assistance from the Legislative Assembly of Cameroon (ALCAM). Such legal means 
were contained in four executive bills which were then approved by 34 to 14 votes on 22 \& 27 May 1959 through law 59/33 of 27 May 1959 on the maintenance of public order. For the first time, legislation formally provided for two specific emergency laws, namely l'état d'alerte (a state of alert) and l'état de mise en garde (a state of warning). ${ }^{8}$ As emergency institutions, a state of alert and a state of warning could be declared by both the interior minister and prime minister in case of 'serious presumption or event threatening public order'. ${ }^{9}$ Whereas a state of warning could not last more than eight days, a state of alert could last for up to three months. Both measures were renewable and had several purposes including the prohibition of meetings and publications, the establishment of curfews and the request for various administrative permissions. People who did not comply with these provisions could be imprisoned for 12 months or pay a fine between 200.000 and 500.000 FCFA. $^{10}$

Through a state of warning and a state of alert the abuse of power which had previously been carried out in secret by the government against the UPC was now openly justified. The main characteristic of this emergency legislation was the fact that public authorities were vested with extensive powers and in return were neither accountable, nor responsible. This legislation provided carte blanche to crack down on human rights, sideline political challengers and hunt the UPC's leaders. In so doing, special criminal tribunals were set up in Bafia, Douala, Dschang, Nkongsamba, Yaounde and large numbers of 'suspects' were arrested. Six opposition newspapers, including Bebey Eyidi's L'opinion au Cameroun, were suppressed. The creation of special criminal tribunals by authorities in such circumstances was a strategy which appeared not only to target the nationalist leaders but also anyone who could succumb or have sympathy for their ideology. This was a critical step in the use of exceptional powers to weaken the struggle of independence and the strategy successfully crossed the boundary of space and time and now plays a central role in the current Cameroon system of governance.

\section{The impacts of a state of exception on current Cameroon institutions}

To properly account for the impacts of a state of exception in 'postcolonial' Cameroon, I shall be looking at two points: firstly, the reconstruction of colonial patterns and secondly, the legal regime of a state of exception.

\section{The reconstruction of colonial patterns}

It is important to start this section based on the premise that 'postcolonial' African nations were not erected from scratch. They were strongly influenced by the techniques and practices used during colonialism. This is evident in the following statement:

... postcolonial African regimes have not invented what they know of government from scratch. Their knowledge is the product of several cultures, heritages, and traditions of which the features have become entangled over time, to the point where something has emerged that has the look of 'custom' without being reducible to it, and partakes of 'modernity' without being wholly included in it. (Mbembe 2001: 24)

The following developments emphasise the idea according to which the postcolonial era in Cameroon has been marked by the transition from colonialism to what is referred to as coloniality. Coloniality is: 
defined with reference to long-standing patterns of power that emerged as a result of colonialism, and continues to define culture, labour, relations, and knowledge production, well beyond the strict limits of colonial administrations. (Maldonado-Torres 2007: 243)

After the 'independence' of Cameroon under French administration on 1 January 1960, exceptional powers vested in President Ahmadou Ahidjo were incorporated into the new constitution of 4 March 1960. The provisions on emergency laws in section 20 were directly inspired by those of section 16 of the French constitution of 4 October 1958 . Section 20 provides for two brand new emergency institutions, namely a state of exception and a state of emergency. Until then emergency institutions referred to a state of alert and a state of warning, both of which have been previously analysed. The release of a constitution, the declaration and extension of a state of emergency did not change the chaotic political climate across the French administered area of Cameroon. The maquis has been persistent and even spread in areas where it did not exist before. Following the same pattern, on 8 March 1960 Ahidjo decreed a state of emergency within 11 troubled divisions of the country for a period of four months, which was renewable indefinitely. A state of emergency extended indefinitely meant an indefinite suspension of law and human rights, a situation characterised by insecurity and violence. Similar to the previous cases, the exception has not been enforced because of a foreign threat to the country's safety or natural cataclysms as intended, but owing to the ongoing UPC's claims for genuine independence. It is noticeable that even though the country has become an 'independent' entity, the techniques of governance characterised by oppression and brutality inherited from the colonial era were to survive. As rightly observed by Sabelo Ndlovu-Gatsheni:

African nationalism then reproduced colonial violence and authoritarianism, bequeathing it on postcolonial Africa as a mode of governance. Only now the violence was justified in the names of the national unity, security, and postcolonial development seen as necessary to secure a postcolonial modernity. (2012: 421)

The ZOPAC appeared to be successful in the Sanaga-Maritime division. But following the cowardly assassination of Um Nyobe on 13 September 1958, the struggle of independence escalated in the Bamileke region. French colonial authorities therefore attempted to repeat the ZOPAC in that portion of the state. Between 1962 and 1963 they forcefully setup concentration camps in that area with the blessing of President Ahidjo. As it is currently reported:

in the Bamileke region, the heart of the device's control remains the 'camps de regroupement' [gathering camps] of populations which increase and consolidate the isolation of 'sane' populations from the populations 'contaminated' by the rebellion. (Deltombe, et al 2011: 543)

To achieve such a task without any opposition, hundreds of thousands of people lived behind a barbed wire fence and in the shadow of watchtowers under the implacable surveillance of politico-military authorities (Deltombe, et al 2011: 543). It is further submitted that these camps were qualified by many as 'concentration' camps where the living conditions were appalling. By May 1962, 85 camps were established in the Bamileke division and held 'the entire population of the five departments of that region' (Deltombe, et al 2011: 544). The UPC grew concerned about Ahidjo who had been sworn in as the president of the 'new independent state' two years previously in January 1960. The movement 
was aware of certain realities: the persistence of colonialism and the perpetuation of a relationship of domination and exploitation; in other words, coloniality had filled up the postcolonial state. This led to a fierce resumption of struggles for genuine independence in the Bamileke division. The maquis was intensified as strikes and insecurity became the daily routine of the population. From one repression to another, Ahidjo, on the ground with full powers granted by the constitution since 1 October 1961, requested from the French army an extensive 'clean-up operation' (Deltombe, et al 2011: 21) within the Bamileke, stronghold of the liberation movement. The operation resulted in the massacre of thousands of people from the Bamileke tribe including nationalist fighters and civil populations. The French army, through an airstrike campaign, bombed the region indiscriminately, erasing entire villages and their inhabitants. It is currently reported that a mass destructive weapon such as napalm might have been used against local populations (Deltombe, et al 2011: 420-3). Such events currently raise issues on what is currently known as the 'Bamilekes' genocide' in Cameroon. ${ }^{11}$ Connecting these developments to the idea of reconstruction of colonial patterns, a similar operation had already happened in the Sanaga-Maritime division during 1957-1958 when Andre Marie Mbida was prime minister. Following the resistance by the UPC movement under the aegis of Um Nyobe who came from the Bassa tribe, several villages occupied by people from this tribe were erased by the French army which at the time was coupled with African soldiers from other French colonised countries led by Colonel Jean-Lamberton (Deltombe, et al 2011). Hunted down, captured, tortured and 'expelled' to their local region by the ruling class, the anti-Bassa propaganda became manifest across the country (Deltombe, et al 2011). Following these descriptions, it appears that the border between past atrocities and present inhumanity has become blurred. Indeed, one may fully agree with the popular maxim according to which 'beyond the equator there are no sins' (De Sousa 2007: 49), which is to say:

... in dealing with non-Westerners/non-Europeans/black peoples, ethics, laws, and other social sanctions that regulated life in Europe and other Western parts of the world had to be suspended and the law of nature, including violence, became legitimate. (Ndlovu-Gatsheni 2012: 425)

In the same vein, Fanon (2008) finds a close parallel between the atrocities of today and those perpetrated during the colonial era with man at the centre. According to him:

the inhumanity of today is not different from the inhumanity of yesteryears for all sources of exploitation resemble one another; they are all applied against the same 'object': man. (Fanon 2008: xix)

The bloodshed perpetrated by a foreign army on local populations at the request of the local 'leader' amounts to the use of a state of exception as a technique of empire happening in Cameroon since the 1950s. The ongoing state of exception had to be implemented not because of genuine exceptional circumstances but against the enemy from within. To achieve such a task perfectly, Franco-Cameroon authorities went as far as to perform public executions to discourage contestations and protests against the system. There are instances where UPC members and sympathisers (labelled 'terrorists') had been beheaded following public executions. The terrorists' chopped-off heads were then exhibited on the market place (Deltombe, et al 2011: 547). This occurred on 3 January 1964 
when 40,000 people attended the public execution of Kamdem Ninyim, a former traditional ruler and collaborator of the administration. A few years later on 15 January 1971, a similar event occurred in the city of Bafoussam that witnessed the public execution of Ernest Ouandie, nationalist fighter and chairman of the UPC. The compulsory public attendance of these executions was a warning to any person intending to challenge and question the political system in place. The gruesome exhibition at markets could be seen as both a celebration, displaying the trophies of the winners, and a dissuasion, discouraging potential candidates to contest the current order. Such a cynical enterprise could only be possible within what De Sousa Santos describes as the 'urban savage zone' that amounts to 'the Hobbes' state of nature, the zones of internal civil war as in many mega-cities throughout the Global South' (2007: 59). The urban savage zone is about nothing but lawlessness that characterises the appropriation/violence paradigm grounded on bestiality and perversity inherent to the techniques of empire. This is in line with the following observation by Mbembe:

Thus, it was through the slave trade and colonialism that Africans came face to face with the opaque and murky domain of power, a domain inhabited by obscure drives and that everywhere and always makes animality and bestiality its essential components, plunging human beings into a never-ending process of brutalization. (2001: 14)

President Ahidjo was re-elected in 1975 and 1980 and resigned on 4 November 1982. In his resignation speech, he transferred power to his constitutional heir, the then prime minister, Paul Biya. The latter inherited a political system with more emphasis on emergency powers and a poor agenda on human rights and the rule of law. Like his predecessor, President Biya was to be charmed by the use of the exception as a political device to sideline political challengers, cling to power and put human rights on hold. With regard to the right to life for instance, the events which occurred in the aftermath of the failed coup d'état of 6 April 1984 is an example in point. As reported:

\footnotetext{
Biya's reactions to this coup attempt were rapid. The most obvious steps were a tightening of security all over the country (a six-month state of emergency was declared in the Yaounde area) and the removal of a number of government officers. Trials of those convicted may have begun as early as 1 May, only three weeks after the attempt. By mid-May the government admitted that 1,053 people had been arrested, but that over half had been set free, and that 46 had been executed. Three others, unnamed but probably including Ahidjo, were sentenced to death in absentia. Amnesty International has claimed that as many as 120 executions took place. (Delancey 1989: 72)
}

Many others were imprisoned and died in their cells due to ill treatment after state confiscation of their heritage. At this moment in time, the struggle for genuine independence had faded, as the UPC resistance had been (finally) overcome. Indeed, the chairman of the movement, Felix Moumie, had been poisoned and died in Switzerland in 1962, the secretary general, Um Nyobe, had been assassinated in the forest in 1958 and the deputy chairman, Ernest Ouandie, was publicly gunned down in 1971. Yet looking at the events of April 1984, a state of emergency was enforced as in the colonial era; to protect the regime from collapsing. An attempted coup d'état is not to be considered as an 'exceptional threat to the life of the nation' or 'circumstances so warrant' to the nation's territorial integrity. As rightly observed: 
the commentary to the draft guidelines for the development of legislation on states of emergency suggests that even serious disruption of the organised life community would not constitute sufficient grounds for a state of emergency if the disruption would not present a serious danger to the life, physical security, or other vital interests of the population. (Fitzpatrick 1994: 56)

But it is obvious that the above requirement from the commentary to the draft guidelines is alien to the appropriation/violence paradigm where there is only one law, that of the strongest, characteristic of the urban savage zone. In addition, as claimed by De Sousa Santos (2007), the fact that the legal principles in force in civil society (or in the regulation/ emancipation paradigm) do not apply within the colonial territory does not in any way compromise their universality. Similarly, Ndlovu-Gatsheni points out that 'while in metropolitan societies, truce, peace, and friendship applied to social life, within the colonial zones, the law of the strongest, violence, and plunder reigned supreme' (2012: 424).

Similar use of a state of exception in 'post-colonial' Cameroon to deal with ethnic targeting remains the principle of divide and rule as exemplified in the above cases of the Bassa and Bamileke tribes. This principle aimed to skilfully divide portions of populations with different ethnic and cultural backgrounds by setting them against one another. The recent developments that unfolded following the presidential election of 7 October 2018 are an example in point. A day following this election, whereas people were still awaiting results from the Constitutional Council, only authority entitled to do so within 15 days, Maurice Kamto, one of the candidates took to the media and, based on information in his possession, declared what appeared to be the trends in his favour; information gathered from various local polling stations as well as abroad. Even though, this candidate did not formally proclaim the results per se, for he never alluded to any statistics or numbers, the situation quickly degenerated into uncontrolled tribal tensions, war of words, threats and promises of hells and heavens among one another across the mass media. The fact is that Kamto is from the Bamileke tribe and his move was basically perceived and interpreted as someone wanting to usurp power from current president Biya who is from the Beti/ Yezoum tribe; something which (irrespective of the amount of democratic process involved) cannot be conceived by some people or group of people inside or outside the country. The striking fact was that later, while contesting the outcome before the Constitutional Council, some of the parties involved were not shy to divert from legal and technical arguments and, in an attempt to score points chose instead to raise tribal tensions supposedly manufactured by Maurice Kamto. In addition to this, some Cameroon citizens who enjoy an international stature and therefore appeared in the society's eyes as models also ended up falling badly into the bottomless pit of tribalism by taking sides and openly cursing Kamto and their countrymen from other tribal groups. It is a pity that to date, the major part of Cameroon citizens continues to miss the point by failing to understand that tribalism is nothing but the most relevant deadly device in the hands of the ruling class to divide and rule. It is unfortunate that people still resist to draw lessons from what occurred in Rwanda and former Yugoslavia or even the current tribal tragedy unfolding in the youngest nation on earth, South Sudan. To date, some Cameroonians willingly agree to be part of this despicable tactic of the regime. Many people have not hesitated to go far so as to stigmatise even people from their own tribe either for a fistful of francs CFA or obscure motivations that can only find some shadow of rationale in the twilight zone. This practice confirms that the ongoing process of producing 
collective insanity introduced decades ago through French technique of imperialism still functions perfectly. The fact that following Kamto's appearance on media, thousands of ordinary citizens submerged by this collective unconsciousness rushed to the social media to vomit indescribable things toward their compatriots supports my earlier submission that tribalism in the country is the key element of the survival of the regime. As long as people continue choosing not to awaken from this unconscious belief and stick to their senses to judge and curse, they will remain at the mercy of the ruling class like it has been the case for the past several decades. The principle of divide and rule within the context of Cameroon can well be explained through Michel Foucault's definition of 'state's racism' as being far from the classical meaning of racism considered to be 'the unfair treatment of people who belong to a different race; violent behaviour toward them.$^{12}$ Racism here is:

A racism which society will direct against itself, against its own elements and its own products. This is the internal racism of permanent purification, and it will become one of the basic dimensions of social normalisation. (Foucault 2003: 62)

Cameroon is formed by a complex multicultural landscape with nearly 300 local languages, a principal division between Anglophone (estimated at around 20 per cent of the population) and Francophone. Democracy in the country is strongly influenced by tribal and linguistic affiliations like during the colonial era. The current president of the republic, Paul Biya, comes from the Beti/Yezoum tribe, located in what is currently referred to as the Big South, formed by three regions, namely the south, the east, and the centre. The president mostly gains support from this area irrespective of his political agenda. The other portions of the state are presumed to belong to the opposition and are by definition considered hostile to the president and his tribe. In June 1991 following the opération ville morte (ghost town operation), resulting from a poor response to growing democratic demands and his denial to organise a national conference, President Biya enforced a de facto state of emergency in the entire country, except in the three provinces that supported his politics. The de facto state of emergency was realised by placing seven of the ten provinces of the country under a statut special, by setting up what was labelled 'Commandement Militaires Operationnels' (Military Operational Command) to 'pacify' the country. This resulted in the deployment of draconian measures, tightening of security, human rights violations, and army brutality committed in taking control of the cities. In so doing, the presidential decree drew a line between the inhabitants of the same country, showing them to be unequal before the law. This approach of using a state of exception to frighten a portion of the population is a sequel of the techniques of empire implemented against the UPC.

Another instance of the use of the exception as a political weapon occurred in 2008. This year was marked by a global financial crisis resulting in inflation and international unrest. In Cameroon two events emerged: the general inflation that led to what has been labelled 'hunger's riots' (émeutes de la faim) and a governmental bill regarding the constitutional amendment to the section that prevented President Biya, in power since 1982, from running for another term. In February 2008 several people peacefully demonstrated on the streets to express their disagreement. Though a state of exception or a state of emergency had never officially been enforced in terms of the provisions of section 9 of the constitution, ${ }^{13}$ the Rapid Intervention Battalion (BIR), a commando unit, was brought in 
to repress the protesters. Systematic use of violence, torture, and killings recurred. Reacting as a private militia in charge of protecting the regime, the BIR has never been trained to deal with public order and to settle disturbances in urban areas. As a result of their brutal reprisals in 2008 more than 139 people were gunned down, according to a report by the National Committee of Human Rights, hundreds more according to non-governmental organisations (NGOs). Such a déjà vu experience strongly emphasises the traumas inherited from independence struggles. Today, coloniality is the new reality taking place within the postcolonial state with violence as its fundamental feature. Fanon coined the continuation of violence after colonialism as follows:

The atmosphere of violence, after having coloured all the colonial phase, continues to dominate national life, for as we have already said, the Third World is not cut off from the rest. This is why the statesmen of under-developed countries keep up indefinitely the tone of aggressiveness and exasperation in their public speeches which in the normal way ought to have disappeared. (1963: 60)

The last case of the reproduction of colonial patterns by the regime in Cameroon is linked to the instance of prohibited areas and concentration camps. I have already elaborated on how prior to 'independence' people were contained in prohibited areas and gath-ering camps. Similar techniques are still enforced today. There have been special areas in the country where some categories of prisoners, especially former pillars of the regime, now in disgrace, are incarcerated. An example of such area is the secrétariat d'état à la défense (SED) (secretariat of state defence) located within the headquarters of a military compound in the capital city, Yaounde. These premises are under military control and not the usual staff of prison guards. Moreover, by two orders on 25 May 2012, the minister of Justice established what was referred to as 'the secondary prisons' in Yaounde $\mathrm{XVI}$ and Douala I. The second order appointed the directors of these secondary prisons. One of the peculiarities of the new secondary prisons is about their physical locality which remains unknown. In the course of an interview, Dieudonné Engonga Mintsang, director of the New Bell Prison in Douala and director of the new secondary prison in the same city, acknowledged that he still ignored the geographic location of the secondary prison under his command. ${ }^{14}$ The idea of a secondary prison espouses the idea of camps and prohibited areas designed to weaken the struggle of independence and reunification. Like the camps, the secondary prisons cannot be considered as prisons according to the usual meaning of the word. The media refers to these secondary prisons as 'fictitious prisons' or 'Cameroon Guantanamo'. The reality is that almost everyone failed to notice the close proximity between such secondary prisons and a space devoid of law. Unlike the previous prohibited zones, which were confined to the camps and areas with barbed wire fences, the new secondary prisons appear to be more lethal since their location has never been mentioned by the orders which brought them into being. By refraining from specifying their physical locality, the ministerial orders of the secondary prisons have removed the barbed wire fences and the walls of the camps that delineated the former prohibited areas from the space of law. Both spaces now merge into each other and expand across private and political spheres. The inhabitants of the country could be (legally) stripped from their rights and withdrawn from the sphere of law at any time and any place. This recurrence and reliance on colonial patterns to rule the country amount to the fact that 'the state's obsession with remaking the past in its own image remains a most 
conspicuous characteristic of the regimes that have come to power in Cameroon since the colonial era' (Mbembe 2001: 18).

\section{The legal regime of a state of exception in Cameroon: an Act of State}

On 18 January 1996, law 96/06 to amend the constitution of 2 June 1972 in Cameroon was published. The emergency institutions as provided for by section 9 remain a state of emergency and the so-called state of siege. An Act of State is that which emanates directly from the president of the republic and is subject neither to parliamentary approval nor to judicial review. Section 22 of ordinance 72/6 of 26 August 1972 on the organisation of Supreme Court reads that 'no court or tribunal is entitled to rule on acts of state'. This provision recurred in section 4 of law 2006/022 of 29 December 2006 on the organisation of the administrative courts which reads as follows: 'No court is entitled to rule on acts of state.'

In the case of Kouang Guillaume Charles against the State of Cameroon, ${ }^{15}$ the administrative court points out the characteristics of an Act of State by ruling that 'one refers to an Act of State when it is about a political matter of an exclusive governmental concern'. The court went on to provide various categories of Acts of State. These include inter alia those pertaining to the diplomatic relationships of the state with foreign countries, the governmental acts issued in its relationships with parliament and presidential acts convening the Electoral College and declaring a state of emergency or a state of siege.

The rationale behind the concept of Act of State is as follows: in his prerogative to enforce a state of exception, the president acts as if the executive power was the only structure to rule the state and this logic can well fit within the appropriation/violence paradigm deprived of any idea of collaboration and accountability among the state's structures. In 1992 for instance amidst the winds of democratisation that blew over Africa and the deteriorating atmosphere characterised by political unrest and instability across the country, a presidential decree setting up an agenda for early presidential elections was issued. The judicial action before the court aiming to cancel the decree was unsuc-cessful as the judge ruled that the presidential decree was an Act of State above his com-petence. Moreover, since the amendment to the constitution in April 2008, the notion of Act of State has been expanded and constitutionalised. The irresponsibility of the presi-dent of the republic during and after his office is clearly entrenched in the new section 53(3) as follows:

Acts committed by the President of the Republic in pursuance of articles 5, 8, 9 and 10 above shall be covered by immunity and he shall not be accountable for them after the exercise of his functions.

The Act of State is a clear reference to the idea of raison d'état and as such remains a veil of irresponsibility and unaccountability of the president during and after his term. Such attributes are close to those of the techniques of empire. An extended development about the concept of Act of State is available elsewhere (Kamdem Kamga 2016).

\section{Conclusion}

Cameroon was born in a state of emergency following a de facto colonial enterprise by Britain and France and a war of liberation led by the UPC movement. The exception 
which remains a legacy of French imperialism has become a key instrument to legalising strategies of control and subjugation of people. Officials in the country cherish the process of operating within the appropriation/violence paradigm through which it is inherently easy to deny a fair democratic game, eliminate political opponents and keep control of power, people and resources. In so doing instead of being a circumstantial remedy to a particular emergency, a state of exception within the context of Cameroon amounts not only to a technique of empire but is a genuine symptom of coloniality. This practice which was introduced in Cameroon by France, a country with 'high democratic culture' needs to be seriously scrutinised and addressed. A radical reform of the legal politico system of the country would be a promising starting point. People are yet to realise that over the years, the systematic use of violence and the persistence of the Hobbesian state of nature have paved the way for the rise of national and transnational crimes with the intensification on Cameroon soil of Boko Haram's activities, a fearsome terrorist organ-isation from Nigeria.

\section{Notes}

1. This is the full version of a paper presented at the conference 'Law between global and colonial: techniques of empire' held at the Erik Castrén Institute of International Law and Human Rights, University of Helsinki, Finland 3-5 October 2016.

2. On page 332 of his book Richard Joseph (1977) provides 'a detailed analysis of one of the most striking examples of anti-colonialism in tropical Africa: the struggle for power of the radical nationalist party, the Union des Populations du Cameroun'.

3. The colonial history of the country was already brilliantly depicted by authors such as Achille Mbembe (2001), Mongo Beti (1984), Abel Eyinga (1978), Richard Joseph (1977), Mark Delancey (1989) and several others.

4. See law 2014/028 of 23 December 2014 on the suppression of acts of terrorism.

5. On 4 April 2011, parliament enacted legislation empowering the president to request access to private emails, monitor the telephone traffic of people and waive the immunity of parliament members.

6. Sections $1 \& 2$ of the decree of 9 November $1901<$ http://djibouti.frontafrique.org/?toDo= docs $\& \mid D=260 \&$ pos $\mid D=116 \geq$ (accessed 5 May 2017).

7. Journal Officiel du Cameroun, Yaounde 1921: 88.

8. Journal Officiel du Cameroun, Yaounde 1959: 637.

9. Ibid.

10. Journal officiel du Cameroun, Yaounde 1959: 637.

11. Felix Moumie, chairman of the UPC at the time used the word 'genocide' in his speech before the fourth UN commission on 28 October 1958 (see Deltombe, et al 2016: 240).

12. See the electronic Oxford Advanced Learner's Dictionary.

13. In a previous article, I have analysed the procedures of the declaration and enforcement of a state of emergency and a state of exception in the country, see Kamdem Kamga (2013).

14. 'Justice: Laurent Esso crée des prisons fictives' <http://www.cameroon-info.net/stories/ 0,34746,@,justice-laurent-esso-cree-des-prisons-fictives.html $\geq$ (accessed 29 April 2017).

15. Kouang Guillaume Charles v Etat du Cameroun jugement 66 ADD/CS/CA du 31 Mai 1979.

\section{Note on Contributor}

Gerard Emmanuel Kamdem Kamga is researcher and project manager at the Centre for Sexualities, Aids and Gender (CSA\&G) Faculty of Humanities at the University of Pretoria. He is also a research fellow at the Free State Centre for Human Rights, Faculty of Law, University of the Free State. 


\section{References}

Agamben, G. 2005. State of Exception. Chicago: University of Chicago.

Awasom, N. 2002. 'Politics and constitution- making in Francophone Cameroon 1959-1960'. Africa Today 49(4): 3-30.

Beti, M. 1984. Main Basse Sur Le Cameroun. Rouen: Peuples Noirs.

Bouvenet, G-J. \& Bourdin, R. 1956. Codes et Lois du Cameroun. Yaoundé: Imprimerie Coulouma.

Cooper, F. 1994. 'Conflict and connection: Rethinking colonial African history'. The American Historical Review 99(5): 1516-45.

Delancey, M. 1989. Cameroon Dependence and Independence. USA: Boulder.

Deltombe, T., Domergue, M. \& Tatsitsa, J. 2011. Kamerun! Une Guerre Cachée Aux Origines De La Françafrique 1948-1971. Paris: Editions de la Découverte.

Deltombe, T., Domergue, M. \& Tatsitsa, J. 2016. La Guerre Du Cameroun, L'invention de la Françafrique 1948-1971. Paris: Editions de la Découverte.

De Sousa Santos, B. 2007. 'Beyond abyssal thinking: From global lines to the ecology of knowledge'. Review XXX(1): 45-89.

Eyinga, A. 1978. Mandat D'arrêt Pour Cause D'élections: De La Démocratie Au Cameroun 1970-1978. Paris: L'Harmattan.

Fanon, F. 1963. The Wretched of the Earth. (Preface by Jean-Paul Sartre, Constance Farr, trans). New York: Grove Press.

Fanon, F. 2008. Black Skin, White Masks (Charles Lam Markmann, trans). London: Pluto Press.

Fitzpatrick, J. 1994. Human Rights in Crisis: The International System for Protecting Rights During States of Emergency. Philadelphia: University of Pennsylvania Press.

Foucault, M. 2003. 'Society must be defended'. Lecture at the College de France 1975/1976. New-York: Picador.

Joseph, R. 1977. Radical Nationalism in Cameroun: Social Origins of the U.P.C. Rebellion Oxford: Oxford University Press.

Kamdem Kamga, G.E. 2013. 'L'Etat d'exception and/or a state of siege: what is really wrong with section 9(2) of the constitution of Cameroon? Fundamina a Journal of Legal History 19(2): 333-51.

Kamdem Kamga, G.E. 2016. 'Starting the emergency process: Some reflections on presidential prerogatives in South Africa and Cameroon in time of turmoil'. VRUe/Law and Politics in Africa, Asia, Latin America 49(1): 91-103.

Maldonado-Torres, N. 2007. 'On the coloniality of being'. Cultural Studies (21)2/3: 240-70. Mbembe,

A. 1984. Le Problème National Kamerunais. Paris: L'Harmattan.

Mbembe, A. 2001. On the Postcolony. California: University of California Press Berkeley \& Los Angeles.

Ndlovu-Gatsheni, S.J. 2012. 'Beyond the equator there are no sins coloniality and violence in Africa'. Journal of Developing Societies 28(4): 419-40.

Roumy, F. 2006. 'L'origine et la diffusion de l'adage canonique necessitas non habet legem' (VIII-XIIIe S), in W. Müller \& M. Sommar (eds), Medieval Church Law and the Origins of the Western Legal Tradition, a Tribute to Kenneth Pennington. Washington: Catholic University of America Press.

Schmitt, C. 1985. Political Theology, Four Chapters on the Concept of Sovereignty. Massachusetts: MIT Press. 